\title{
Occurrence of moulds inEgyptianprocessed peanut and control of aflatoxicfungi by some powder spices
}

\author{
Mona I. Fahd $;{ }^{1}$ Hassan A. Amra; ${ }^{2}$ Feriala A. Abo-seif ${ }^{1}$ and Walaa,N. Mohammed ${ }^{1}$ \\ 1. Botany Department, Faculty of Women for Arts, Science and Education- Ain \\ Shams University. \\ 2. Food Toxicology and Contaminants National Research Center,Cairo, Egypt.
}

\begin{abstract}
Due to its high protein and lipid content, peanut are greatly appreciated by consumers but is very susceptible to aflatoxic fungi contamination indicates that there is a potential hazard of aflatoxins contamination in Egyptian processed peanuts and that requires resistance to this fungus. The current work aimed to study the occurrence of molds in peanut products as well as the antifungal properties of ten powder spices (Cloves, Black pepper, Cinnamon, Peppermint, Thyme, Cardamom , Cumin, Ginger, Onions and Fenugreek) at different concentration $4,7,10 \mathrm{mg} / \mathrm{ml}$ in broth yeast extract sucrose media (YES) against aflatoxigenicAspergillusflavus fungi associated with peanut products. Samples(Row,Roasted,Roastedwith salted and with spices) were collected from five locations ( Cairo,Suez, Monofia of north Delta and Fayoum and Luxor of south Delta ) during one year from ( winter 2013 to autumn 2014). Four fungal genera were isolated Aspergillus( 8.30-38.97\%), Penicillium ( 2.98 - $18.98 \%)$, Fusarium (2.96-8.98\%) and Rhizopus $(0.98-11.95 \%)$.Aspergillus section flavi was the most common. One way ANOVA indicated that there is significant among the five Governorates in their infection percentage of peanut by Aspergillus spp., but no significance difference in their infection percentage of peanut by Penicillium spp., Rhizopus spp. and Fusarium spp. Alsothe results revealed that A.flavus and A. parasiticus isolates produced aflatoxins.. It is noticed that clove powder is the most effective spice which completely inhibited A. flavusgrowth and aflatoxins production in broth media and in peanut seeds, while other spices only inhibit aflatoxins production at $10 \mathrm{mg} / \mathrm{ml}$ but allow fungal growth at this concentrations ,but did not inhibit the fungal growth or aflatoxins production at 4 and $7 \mathrm{mg} / \mathrm{ml}$.It is noticed that the minimum inhibitory concentration ( MIC) of clove was at $3 \mathrm{mg} / \mathrm{ml}$. As well as the effect of spices ( clove, cinnamon,thyme and peppermint) on A. flavus in raw peanut seeds showed that the fungal growth was noticed at all the concentrations $(4,7$ and $10 \mathrm{mg} / \mathrm{g}$ ) but it was weak at $10 \mathrm{mg} / \mathrm{g}$ of clove. Aflatoxinsproduction were inhibited at $10 \mathrm{mg} / \mathrm{g}$ spices( clove , cinnamon, thyme and peppermint as well as at $7 \mathrm{mg} / \mathrm{g}$ clove and cinnamon inhibit aflatoxins production. On the other hand at $7 \mathrm{mg} / \mathrm{g}$ of peppermint and thyme reduced the aflatoxinsproduction till 22.3 and $30 \mu \mathrm{g} / \mathrm{kg}$ respectively. At $4 \mathrm{ml} / \mathrm{g}$ of spices concentration( clove, cinnamon, peppermint and thyme) aflatoxins production were reduced to $20,30,43.8$ and $50 \mu \mathrm{g} / \mathrm{kg}$ respectively in peanuts for 7 days.
\end{abstract}

Key words: Antifungal, spices, peanut seeds, locations, fungi, seasons.

*Corresponding author: drlolomicro@yahoo.com 


\section{Introduction}

Peanut (Arachishypogaea $L$ ) is one of the most important food and oil seed crops cultivated and utilized in most parts of the world. Peanut seed contain 50\% edible oil. Seeds are rich in fats, protein, vitamin $\mathrm{B}_{1}, \mathrm{~B}_{2}, \mathrm{~B}_{6}$, nicotinic acid and other vitamins. peanuts are unique among cultivated crops in that produce seeds-bearing pods below the soil surface. Pods are in direct contact with soil population and the seeds are frequently invaded by soil fungi before harvest (Homet al .,1995).Fungi can grow on simple and complex food products and produce various metabolites. These microorganisms exist in the environment and distribute by wind, insects and raining (Bruset al., 2005). Up to now, more than 100000 fungal species are considered as natural contaminants of agricultural and food products (Kacaniova, 2003). The majority of the toxic species belong to the genera Aspergillus, Penicillium and Fusarium(Oluma and Nwankiti ,2003)

A major problem related to fungal attack in nuts is the production of toxic secondary metabolites, particularly fumonisinzearaenone and aflatoxin, produced by $F$. verticillioides F. graminearum and A. flavus, respectively(Scott, 1993). According to the FAO2011( Food and Agriculture Organization ) 25\% of the world's crop harvests are contaminated with mycotoxins. There are currently more than 400 mycotoxins known. Previous studies showed that 30.97 million tons of greasy seed products, mainly pistachio and peanut, of different Asian and African countries were contaminated by Aspergillusflavus(A flavus) and A.parasiticus(Dekoeet al., 2000)Several investigations have listed a large number of fungi which could be isolated from peanuts during storage (Horn 2005 ) Aspergillusflavus is the dominant storage fungus colonizing peanuts, capable of causing seed rots, molding of seeds, pre-and post-emergence damping off, and reducing seed viability and seedling growth in peanuts (Kumar et al 2008, Horn and domer 2009). Colonization of peanuts with mold fungi is of importance because of its potential to produce aflatoxins, which are potent toxic, carcinogenic, mutagenic, immunosuppressive, and teratogenic agents (Rivka 2008a, Rivka 2008b).

The storage temperature, moisture content, presence of oxygen and gaseous composition are the most important factors influencing the development of fungi during storage (Kubatova, 2000). The long growing season, warm weather, and available 
humidity in the growing areas are favorable conditions for peanut production. These conditions are also favorable for many fungal pathogens to attack peanut causing harmful diseases and reduce yield as well under field or storage conditions.(Reddy and Rao,1980). The World Health Organization (WHO)defined a medicinal plant as any herbal preparation produced by subjecting plant substances to extraction, fractionation, purification,concentration or other physical or biological process which may be produced for immediate consumption or as a basis for colonization of peanuts with mold fungi is of importance because of its potential to produce aflatoxins, which are potent toxic, carcinogenic, mutagenic, immunosuppressive, and teratogenic agents (WHO, 2001;Rivka 2008a and Rivka 2008b).Phytochemicals often referred to as "secondary metabolities" chemical compounds formed during the plant normal metabolic processes, they were first described at the beginning of the 19th century (Cordell,1995). The most important of these bioactive compounds of plants are alkaloids, flavanoids, quinones, phenolic compounds, saponins, tannins, coumarins, glycosides, gums, polysaccharides, terpenes and other chemical compounds (Leon et al., 2001; Okwu, 2004 and AlZubaydiet al., 2009). In recent years, multiple drug/chemical resistance in both human and plant pathogenic microorganisms have been developed due to indiscriminate use of commercial antimicrobial drugs/chemical commonly used in the treatment of infectious diseases (Anwar et al., 2009). Mould growth is commonly controlled using synthetic antimicrobials; however, natural antimicrobials had also demonstrated important antifungal properties (Lopez-Maloet al., 2000).

The aim of the present search is to determine mycoflora distribution in processed peanuts such as raw ,roasted, roasted and salted and salted with additives from different localities from Egypt in the four seasons(2013-2014), determine the ability of Aspergillusflavusgroup to produce aflatoxins in broth media and assessment the antifungal and anti-aflatoxigenic activity of some spices in broth media and in peanut seeds.

\section{2-Materials And Methods :}

\subsection{Collection of peanut seed samples:}

Eighty seed samples of peanut seeds (each $500 \mathrm{~g}$ ) represented of 4 products of peanuts (Raw -Roasted-Roasted and salted and Roasted with additives ). 
Twenty samples of each type were collected from commercial markets in Egypt located at 5 governorates (Cairo,Suez, Menuofia of north Delta and Fayoum and Luxor of south Delta governorates inEgypt),,during four seasons of winter 2013- Autumn 2014. Samples were kept at $4^{\circ} \mathrm{C}$, until fungal and aflatoxins analysis.

\subsection{Isolation of seed-borne fungi:}

Fungi associated with peanut seeds were isolated according to (Ichinoeet al ,1983) . Peanut seeds samples were immersed in sodium hypochlorite solution 3\%colorex as a sterilizer, for 3 minutes, rinsed 3 times in sterile distilled water then dried between sterile filter paper. A total of 15 peanut seeds in three plates of each sample (5 x 3 replicates) were direct plated on to Petri dish on Potato-Dextrose agar media (PDA). After incubation at $27+-2^{\circ} \mathrm{C}$ for 7 days, the frequency of moulds per seed were recorded. The isolates of Aspergillus section Flavi, A.parasiticus and other fungal flora were recovered from the peanut seeds, purified and maintained on slants of PDA at $3-5^{\circ} \mathrm{C}$, until identification and examination for their toxigenic potential. Incidence was recorded by the following formula

No. of infected seeds

Incidence $\%=$

Total no. of plated seeds

\subsection{Identification of the isolated fungi :}

Pure culture of the isolated fungi was identified at The Regional Center For Mycology And Biotechnology (Rcmb), Al_Azher University (Cairo/Egypt).Stock culture of the identified fungal genera were maintained on slants of potato dextrose ager (PDA) medium, stored at $4^{0} \mathrm{c}$ and subculture was made every two weeks in order to use it in further investigation.

\subsection{Fungi spore suspension preparation :}

The surface cultivated culture of isolated mold fungi in slant was sub-cultured by streaking the spores onto the new slant Potato dextrose agar (PDA) media .New slant 
cultures were then incubated for 7 days at $27 \pm 20 \mathrm{C}$. The spores of 7 -day-old cultures of mold fungi were dislodged by sterile distilled water with $0.1 \mathrm{~mL} / \mathrm{L}$ of Tween 80 .The spore suspensions were then collected and filtered through sterile cloth to remove mycelia and agar fragments, and the aliquot was diluted to a concentration of (1x106 cfu) fungal spores $/ \mathrm{mL}$ with the aid of Hemo- cytometer slide.(Atandaet al,2007).

\subsection{Assay the ability of aflatoxins production by A. flavus :}

One $\mathrm{ml}$ of freshly prepared spore suspension the test organismswith $\left(10^{5}-10^{6} \mathrm{spores} / \mathrm{ml}\right)$ were grown in YES broth media in suitable Erlenmeyer flask. The flasks were still incubated at $25^{\circ} \mathrm{C}$ for 7-10 days. Then media were heated at $80{ }^{\circ} \mathrm{C}$ for $10 \mathrm{~min}$ to inhibit fungal spores and the medium was filtered off and a known volume of the filtrate was extracted with chloroform, purified and subjected to chromatographic analysis.(Singh et al ,1991)

\subsection{Quantitative Estimation of Aflatoxins :}

Analysis of aflatoxins was done using Thin layer chromatography (TLC) and High performance liquid chromatography (HPLC according to (AOAC, 2007). The HPLC instrument used was waters (474) system, equipped with quaternary pump. The fluorescence detector system was set at360 nm excitation and $440 \mathrm{~nm}$ emission wavelengths. The chromatography column was phenomenex c18 (250x $4.6 \mathrm{~mm}), 5 \mu \mathrm{m}$. The mobile phase system(HO: $\mathrm{MeOH}: \mathrm{CH} 3 \mathrm{CN}, 30: 60: 10 \mathrm{v} / \mathrm{v} / \mathrm{v}$ ) was isocratically at flow rate of $1 \mathrm{ml} / \mathrm{min}$ (Han et al., 2004). The data were collected and integrated using Total chrom Navigator Chromatography Manager Software.

\subsection{Anti-fungal and Anti-aflatoxigenic Activity of spices:}

The anti-fungal and anti-aflatoxigenic activity of ten spices (Cloves, Black pepper, Cinnamon, Peppermint, Thyme, Cardamom, Cumin, Ginger, Onions and Fenugreek ) were individually tested against the toxigenic strain of A. flavus at concentration 4 to $10 \mathrm{mg} / \mathrm{ml}$. The spices were grinded and the required weight was added to $100 \mathrm{ml}$ yeast extract sucrose (YES) culture broth taken in $250 \mathrm{ml}$ Erlenmeyer flask and autoclaved at 
$121{ }^{\circ} \mathrm{C}$ for $15 \mathrm{~min}$. Spore suspension of $10^{6} / \mathrm{ml}$ in sterile distilled water was prepared by collecting the spores from 7 days old A. flavus culture. Two hundred and fifty $\mu 1$ of the spore suspension was inoculated into the medium and incubated at $28{ }^{\circ} \mathrm{C}$ for 7 days. A control set without spices was maintained under the same condition. The anti-fungal activity was determined for all the spices after 7 days incubation in terms of mycelia biomass (dry mycelium weight). The fungal growth was heated at $80{ }^{\circ} \mathrm{C}$ for $10 \mathrm{~min}$ to inhibit the fungal spores. The mycelium in the medium was filtered through filter paper and the dry weight was determined by drying at $60 \mathrm{C}^{0}$ in hot air oven till weight became constant. AFBs and AFGs were extracted from the culture broth with equal volume of chloroform $(25 \mathrm{ml} \times 3)$. The extracted AFs were analyzed by TLC and HPLC methods as described in previously explained method.

\subsection{Minimum inhibitory concentration of spices (MIC)}

To assess the minimum inhibitory concentration (MIC) of the tested and positive spices in the previous antifungal test that is clove which inhibited the fungal growth in YES broth media, different concentrations of clove ranging from 1 to $7 \mathrm{mg} / \mathrm{ml}$ were tested following the procedure mentioned previously were calculated as following( Tianet al.,2011).

Mean concentration of AFBs in treatment

Inhibition \% = -

Mean concentration of AFBs in control

\subsection{Anti-aflatoxigenic activity of spices on peanut seeds}

The effect of cinnamon, thyme, peppermint and clove were also proved anti- AFBs production in raw peanut. Raw peanut seeds that had no fungal and AFBs contamination was used for the experiment. $50 \mathrm{~g}$ of raw peanut in $250 \mathrm{ml}$ Erlenmeyer flask were sterilized in oven at $100{ }^{\circ} \mathrm{C}$ for $10 \mathrm{~min}$.. Different weights of spices 4,7 and $10 \mathrm{mg}$ were separately added to a known volume $(8 \mathrm{ml})$ of distilled water and sterilized then 
added to the the sterilized peanut to maintain the moisture content of peanut at the time of inoculation at $22-23 \%$. $250 \mu \mathrm{l}$ of A. flavus spore suspension $\left(10^{6} / \mathrm{ml}\right)$ was inoculated and incubated at $28^{\circ} \mathrm{C}$ for $7-10$ days (Shotwellet al. 1966). After incubation, AFBs were extracted from $50 \mathrm{~g}$ peanut culture directly as privious. Qualitative and quantitative analysis of AFBs were carriedout using TLC and HPLC

\subsection{Statistical analysis}

Standard deviation has been calculated for the studied parameters. In addition, the obtained results were treated statistically using analysis of variance as described by (Snedecor and Cochran 1969). Means were compared by LSD at 5\% using SPSS program Ver. 16.

\section{Results and Discussion}

\subsection{Mould contamination of peanut seeds}

Results in Table(1) illustrate the fungal contamination ( the incidence of infected seeds \%) of aflatoxigenic fungi and the other fungal genera populations from the peanut samples from the five Egyptian Governorates . It noticed that four fungal genera ( Aspergillus sp., Penicillium sp., Fusarium sp. And Rhizopus sp.)were identified. Similar data were obtained by(Embaby and Abdel-Galel, 2014). While (El-Shanshouryet al.,2014) isolated eight fungal genera belonged to Aspergillus, Penicillium, Fusarium, Mucor,Cladosporium, Trichoderma, Rhizopus and Alternaria from maize, wheat, rice and peanut. Its noticed that the highest incidence of infected seeds was with Aspergillus spp. that ranged from (12.03 to 32.44\%) were recorded in seeds from Fayoum and Suez regions respectively. Values of Penicillium and Rhizopus genera in different seeds from different regions were similar ( 5.41 to $12.63 \%$ ) in seeds from luxor and fayoum Governorates, respectively . finally (7.89 $18.49 \%)$ of Fusarium Sp. were recordedin Suez Governorate. One way ANOVA indicated that there is significance among the five Governorates in their infection percentage of Peanut by Aspergillus spp. and there is no significant difference between Penicillium, Rhizopus and Fusariumgenera. Also (Sultan and Magan;2010) reported that there is a significant effects of region on Aspergillus spp.(Youssef et al., 2008) isolated 3 varities belong to 63 species belong to 21 genera of 
fungi from peanuts. They found that the dominant fungal genera were Aspergillus $s p$., Penicillium sp. and Fusariumsp..On the other hand (El-Mohamadyet al., 2014) found that Aspergillusflavus was a common isolated fungus in high frequency from peanut seeds followed by Aspergillusniger and Aspergillusochraceus, The relation between the average rate of fungal contamination of Peanut and seasons are illustrate in Table 2. There is no significant difference among the seasons in the contamination of peanuts by different fungal genera. Aspergillus spp. group was the highest contamination ratio of $27.82 \pm 11.53$ in Spring season then Penicillium spp. of $12.31 \pm 5.72 \%$ in Summer, Rhizopus sp. of $7.27 \pm 2.23 \%$ in winter and Fusariumsp $7.28 \pm 3.22$ \%in spring season .On the other hand (Sultan and Magan ,2010) reported that statistically there is a significant effect of season on Aspergillus spp. Table 3 shows the statistical analysis of the interaction between fungal contamination in relation to different types of peanut samples ( Raw, Roasted, Roasted-salted and spiced) the highest values \%of infection byAspergillus and Rhizopus were recorded in raw peanut followed by spicy peanut of $(38.97-31.90 \%),(8.33-2.33 \%)$ and $(11.95-9.58 \%)$ respectively. While the highest value Penicilliumgenera incidence of infected seeds were detected in Roasted-salted followed by spicy peanut samples of (18.98 -11.45\%) respectively, while the highest value of Fusarium contamination was determined in Roasted followed by Raw and roasted-salted of $(8.98-6.63 \%)$ respectively . (Sultan and Magan,2010) reported that high populations of Cladosporium and Penicillium species were present in peanut samples from Alexandria and El- Sharqiya in 2008 year.( Al-amod ,2015) isolated 3 fungal genera from groundnut seeds in Yemen namely Aspergillusniger, Aspergillusflavus and Macrophominaphaseolina 
Table (1): Fungal genera associated with row and different types of processed peanuts collected from different governorates of Egypt duringwinter 2013 to autumn 2014

\begin{tabular}{|l|l|c|c|c|c|c|}
\hline Fungi & \multicolumn{1}{|c|}{ Cairo } & \multicolumn{1}{|c|}{ Suiz } & Louxr & Menoufia & Fayoum & $\begin{array}{c}\text { F } \\
\text { value }\end{array}$ \\
\hline $\begin{array}{l}\text { Aspergillus } \\
\text { spp. }\end{array}$ & $24.85 \pm 18.6$ & $32.44 \pm 17.85$ & $29.53 \pm 17.7$ & $27.89 \pm 19.8$ & $12.03 \pm 10.1$ & $3.42 *$ \\
\hline $\begin{array}{l}\text { Penicillium } \\
\text { spp. }\end{array}$ & $7.36 \pm 6.72$ & $6.66 \pm 11.14$ & $5.41 \pm 7.77$ & $6.24 \pm 9.87$ & $12.63 \pm 10.6$ & 0.72 \\
\hline Rhizopus spp. & $7.36 \pm 6.72$ & $6.66 \pm 11.14$ & $5.41 \pm 7.77$ & $6.24 \pm 9.87$ & $12.63 \pm 10.6$ & 1.50 \\
\hline Fusarium spp. & $5.39 \pm 12.68$ & $7.89 \pm 8.49$ & $5.40 \pm 6.97$ & $6.24 \pm 8.59$ & $3.70 \pm 6.36$ & 0.47 \\
\hline
\end{tabular}

*Significance at $\mathbf{p}<0.5$

Table (2): Fungal genera associated with row and different types of processed peanutsduringwinter 2013 to autumn 2014

\begin{tabular}{|l|l|l|l|l|c|}
\hline Fungi & \multicolumn{1}{|c|}{ Winter } & \multicolumn{1}{|c|}{ Spring } & \multicolumn{1}{|c|}{ Summer } & \multicolumn{1}{c|}{ Autumn } & F value \\
\hline Aspergillus spp. & $25.29 \pm 6.60$ & $27.82 \pm 11.53$ & $26.40 \pm 10.88$ & $21.89 \pm 6.49$ & 0.38 \\
\hline Penicillium spp. & $11.30 \pm 2.49$ & $11.12 \pm 2.02$ & $12.31 \pm 5.72$ & $7.95 \pm 1.80$ & 1.54 \\
\hline Rhizopus spp. & $7.27 \pm 2.23$ & $6.30 \pm 4.28$ & $5.31 \pm 2.19$ & $4.61 \pm 1.79$ & 0.86 \\
\hline Fusarium spp. & $5.31 \pm 1.85$ & $7.28 \pm 3.22$ & $6.33 \pm 2.47$ & $5.97 \pm 4.50$ & 0.34 \\
\hline
\end{tabular}

There is no significant difference among the seasons in the infection of peanuts by different fungi 
Table (3):Fungalgenera associated with row and different types of processed peanuts samplesfrom winter 2013 to autumn 2014

\begin{tabular}{|l|l|l|l|l|c|}
\hline & \multicolumn{1}{|c|}{ Row } & \multicolumn{1}{|c|}{ Roasted } & Roasted-salted & \multicolumn{1}{|c|}{ With spices } & F value \\
\hline Aspergillus spp. & $\mathbf{3 8 . 9 7} \pm 17.65$ & $\mathbf{2 2 . 2 3} \pm 7.22$ & $8.30 \pm 7.06$ & $31.90 \pm 6.83$ & $7.66^{*}$ \\
\hline Penicillium spp. & $2.98 \pm 2.96$ & $9.28 \pm 2.76$ & $18.98 \pm 3.83$ & $11.45 \pm 5.37$ & $14.56^{* *}$ \\
\hline Rhizopus spp. & $11.95 \pm 5.20$ & $\mathbf{0 . 9 8} \pm 2.19$ & $0.98 \pm 1.46$ & $9.58 \pm 2.14$ & $17.06 * *$ \\
\hline Fusarium spp. & $6.63 \pm 8.71$ & $\mathbf{8 . 9 8} \pm 7.50$ & $6.31 \pm 5.43$ & $2.96 \pm 2.41$ & 0.73 \\
\hline
\end{tabular}

*Significance at $\mathbf{p}<0.5 \quad * *$ Significance at $\mathbf{p}<.001$

\section{Aflatoxins production by Aspergillus spp.in YES broth media:}

The most important factors which affected on fungal growth and aflatoxins production are moisture and temperature .In Egypt grains stored under stress conditions of high moisture $>14 \%$ and warm temperature $>20^{\circ} \mathrm{c}$, these condtions allow fungi to occur in stored grains( Belli et al .,2004), also initial fungal growth in grains can form sufficient moisture from metabolism to allow further fungal growth and mycotoxins production .Data in Table (4) showed that 26(41.94\%) out of 62isolates of $A$. flavus (17, 4, 4 and 1 isolates from raw, spiced, roasted and salted peanut, respectively) and $41(73.21 \%)$ out of $56(15,11,8$ and 7 isolates from raw, spiced, roasted and salted peanut, respectively) fungal isolates of A. parasiticus have the ability to produce aflatoxins $\mathrm{B}_{1}$ and $\mathrm{B}_{2}$ in YES broth media. On the other hand A.oryzae and A.oryzaevareffusus isolates have not the ability to produce aflatoxins in YES broth media. Aflatoxins $\mathrm{AFB}_{1}$ ( of concentration ranged from 6.8 to $74.5 \mu \mathrm{g} / \mathrm{kg}$ ) and $\mathrm{AFB}_{2}$ (of concentration ranged from 2.7 to $94 \mu \mathrm{g} / \mathrm{kg}$ ) were the most common. Also (Sultan and Magan , 2010) found that out of 88 Aspergillus section Flavi strains, $95 \%$ were produced aflatoxin $\mathrm{B}_{1}$ on yeast extract sucrose (YES) medium. (El-shanshouryet al, 2014) reported that $26(78.79 \%)$ out of 33 of A. flavus isolates have the ability to produceaflatoxins $\left(\mathrm{AFB}_{1}, \mathrm{AFB}_{2}, \mathrm{AFG}_{1}\right)$. The average concentrations detected were 205, 
100, 107 and $236 \mu \mathrm{g} / \mathrm{g}$ mycelia dry wt. of the fungus, for $\mathrm{AFB}_{1}, \mathrm{AFB}_{2}, \mathrm{AFG}_{1}$ and total aflatoxins, respectively.

Table (4) Aflatoxins producing ability of A. flavus, A. parasiticus, A. oryzae and A. oryzae effuses isolated from peanut seeds:

\begin{tabular}{|c|c|c|c|c|c|c|}
\hline \multirow[b]{2}{*}{ Fungi species } & \multirow{2}{*}{$\begin{array}{l}\text { NO.of } \\
\text { tested } \\
\text { isolates }\end{array}$} & \multirow{2}{*}{$\begin{array}{l}\% \text { of AFS } \\
\text { producting } \\
\text { isolates }\end{array}$} & \multicolumn{2}{|c|}{$\mathrm{AFB}_{1}$ concentration $\mu \mathrm{g} / \mathrm{kg}$} & \multicolumn{2}{|c|}{$\mathrm{AFB}_{2}$ concentration $\mu \mathrm{g} / \mathrm{kg}$} \\
\hline & & & Range & Mean & Range & Mean \\
\hline A.flavus & 62 & $26(41.94 \%)$ & 6.8-65.8 & 24.3 & $2.7-34.6$ & 13.7 \\
\hline A.parasiticus & 56 & 41(73.21\%) & 4.04-74.5 & 26.9 & 4.0-94 & 23.4 \\
\hline A.oryzae & 28 & - & -- & - & - & - \\
\hline $\begin{array}{l}\text { A.oryzae } \\
\text { effuses }\end{array}$ & 16 & - & - & - & - & - \\
\hline
\end{tabular}

AFS = Aflatoxins

\subsection{Anti-fungal and Anti-aflatoxigenic Activity of spices:}

The antifungal and anti-aflatoxigenic properties of ten spices namely cloves,blackpepper,cinnamon,peppermint,thyme,cardamom,cumin,ginger, onions and fenugreek were individually assessed against the toxigenic strain of A. flavus in YES broth medium are presented in Tables 5,6 and 7. The data illustrated that although clove had completely inhibited mycelial growth at 4,7 and10 $\mathrm{mg} / \mathrm{ml}$ up to 8 days (\%reduction $100 \%$ ), cinnamon, peppermint, thyme, inhibited the aflatoxins production by $100 \%$ at 4,7 and $10 \mathrm{mg} / \mathrm{ml}$ but allow fungal growth at the same concentrations. On the other hand, (black pepper, cardamom, ginger, cumin, fenugreek and onion) did not inhibit the growth and did not reduce aflatoxins production under the same condition. Antifungal activity of these spices and the use of their essential oil against mycotoxin synthesis were reported by (Bokhari, 2007). 
Table(5):GrowthofAspergillusflavusandAflatoxinproductioninthepresenceofspicesin YESmedium at $10 \mathrm{mg} / \mathrm{ml}$.

\begin{tabular}{|l|l|c|c|}
\hline \multicolumn{1}{|c|}{ Spice 10mg/ml } & $\begin{array}{c}\text { Average } \pm \text { SD of } \\
\text { \%mycelial growth } \\
\text { inhibition }\end{array}$ & $\begin{array}{c}\text { \%Reduction of } \\
\mathbf{A F B}_{1} \text { production }\end{array}$ & $\begin{array}{c}\text { \%Reduction of } \\
\mathbf{A F B} \text { production }\end{array}$ \\
\hline Clove & $100 \pm 0.0$ & $100 \%$ & $100 \%$ \\
\hline Cinnamon & $45.55 \pm 0.32$ & $100 \%$ & $100 \%$ \\
\hline Thyme & $44.05 \pm 0.12$ & $100 \%$ & $100 \%$ \\
\hline Peppermint & $30.50 \pm 0.46$ & $100 \%$ & $100 \%$ \\
\hline Black pepper & $59.58 \pm 0.28$ & $100 \%$ & $100 \%$ \\
\hline Cardamom & $26.35 \pm 0.38$ & $100 \%$ & $100 \%$ \\
\hline Ginger & $16.47 \pm 0.14$ & $100 \%$ & \\
\hline Cumin & $45.55 \pm 0.32$ & $60 \%$ & $30 \%$ \\
\hline Onions & $-5.49 \pm 0.37$ & $30 \%$ & \\
\hline Fenugreek & $11.74 \pm 0.16$ & & \\
\hline & & & \\
\hline
\end{tabular}


Table(6):Growth of Aspergillusflavusand Aflatoxin production in the presence of spices in YES medium at $7 \mathrm{mg} / \mathrm{ml}$.

\begin{tabular}{|l|c|c|c|}
\hline \multicolumn{1}{|c|}{ Spice 7 mg/ml } & $\begin{array}{c}\text { Average } \mathbf{4} \text { SD of } \\
\text { \% mycelial growth } \\
\text { inhibition }\end{array}$ & $\begin{array}{c}\text { \%Reduction of AFB } \\
\text { production }\end{array}$ & $\begin{array}{c}\text { \%Reduction of AFB } \\
\text { production }\end{array}$ \\
\hline Clove & $100 \pm 0.0$ & $100 \%$ & $100 \%$ \\
\hline Cinnamon & $54.76 \pm 0.19$ & $100 \%$ & $100 \%$ \\
\hline Thyme & $33.20 \pm 0.31$ & $100 \%$ & $100 \%$ \\
\hline Peppermint & $29.53 \pm 0.29$ & $100 \%$ & $55 \%$ \\
\hline Black pepper & $41.43 \pm 0.49$ & $60 \%$ & $60 \%$ \\
\hline Cardamom & $21.76 \pm 0.21$ & $40 \%$ & $60 \%$ \\
\hline Ginger & $11.36 \pm 0.45$ & $60 \%$ & $30 \%$ \\
\hline Cumin & $6.23 \pm .26$ & $60 \%$ & $20 \%$ \\
\hline Onions & $-6.31 \pm 0.26$ & $30 \%$ & $60 \%$ \\
\hline Fenugreek & $-1.52 \pm 0.49$ & $20 \%$ & \\
\hline
\end{tabular}


Table(7):Growth of Aspergillusflavusand Aflatoxin production in the presence ofspices in YES medium at $4 \mathrm{mg} / \mathrm{ml}$.

\begin{tabular}{|c|c|c|c|}
\hline Spice 4 mg/ml & $\begin{array}{c}\text { Average } \pm \text { SD of } \\
\% \text { mycelial growth } \\
\text { inhibation }\end{array}$ & $\begin{array}{c}\text { \% Reduction of } \mathrm{AFB}_{1} \\
\text { production }\end{array}$ & $\begin{array}{c}\text { \% Reduction of } \mathrm{AFB}_{2} \\
\text { production }\end{array}$ \\
\hline Clove & $100 \pm 0.0$ & $100 \%$ & $100 \%$ \\
\hline Cinnamon & $48.64 \pm 0.33$ & $100 \%$ & $100 \%$ \\
\hline Thyme & $30.45 \pm 0.21$ & $100 \%$ & $100 \%$ \\
\hline Peppermint & $28.68 \pm 0.32$ & $100 \%$ & $100 \%$ \\
\hline Black pepper & $23.00 \pm 0.05$ & $45 \%$ & $45 \%$ \\
\hline Cardamom & $13.48 \pm 0.16$ & $30 \%$ & $25 \%$ \\
\hline Ginger & $10.32 \pm 0.10$ & $40 \%$ & $45 \%$ \\
\hline Cumin & $-2.85 \pm 0.21$ & $30 \%$ & $40 \%$ \\
\hline Onions & $-3.47 \pm 0.22$ & $20 \%$ & $25 \%$ \\
\hline Fenugreek & $-4.13 \pm 0.08$ & $10 \%$ & $10 \%$ \\
\hline
\end{tabular}

\pm Values showed are stander deviation $(n=3) \quad \mathrm{AFB}_{1} \& \mathrm{~B}_{2}=$ aflatoxin $\mathrm{B}_{1} \& \mathrm{~B}_{2}$

\section{Minimum inhibitory concentration of clove:}

Clove inhibited fungal growth at concentration $3 \mathrm{mg} / \mathrm{ml}$ of clove spice in YES broth medium Table 8 . The data illustrated that 1 and $2 \mathrm{mg} / \mathrm{ml}$ concentration of clove decreased the mycelia growth by 83 and $90 \%$ respectively as well as aflatoxins $B_{1}$ was reduced by 90 and $97 \%$ respectively. Clove entirely inhibited fungal growth and $\mathrm{AFB}_{1}$ production at $3 \mathrm{mg} / \mathrm{ml}$ and so the MIC was recorded at this concentration in YES broth medium. 
Table(8):Determination of minimum inhibitory concentration (MIC) of clove

against

Aspergillusflavusgrowthandaflatoxin $\mathrm{B}_{1}$ productioninYESculturebroth.

\begin{tabular}{|c|c|c|}
\hline $\begin{array}{c}\text { Clove } \\
\text { concentration } \\
\mathbf{m g} / \mathbf{m l}\end{array}$ & $\begin{array}{c}\text { \% mycelial } \\
\text { growth inhibition }\end{array}$ & $\begin{array}{c}\text { \% Reduction of } \\
\text { AFB1 production }\end{array}$ \\
\hline $\mathbf{0}_{\text {(control) }}$ & $0 \%$ & $0 \%$ \\
\hline 1 & $83 \%$ & $90 \%$ \\
\hline 2 & $90 \%$ & $97 \%$ \\
\hline $3 *$ & $100 \%$ & $100 \%$ \\
\hline 4 & $100 \%$ & $100 \%$ \\
\hline * MIC concentration & & \\
\hline
\end{tabular}

\section{Anti-fungal andaflatoxigenic of some spices on peanut seeds:}

None of the spices (clove, cinnamon, peppermint and thyme) had inhibited the growth of A. flavus in raw peanut at concentrations of 4,7 and $10 \mathrm{mg} / \mathrm{g}$, while at $10 \%$ of clove the fungal growth was the lowest Table 9. Although the spices did not inhibit fungal growth, AFB production was completely inhibited at $10 \mathrm{mg} / \mathrm{ml}$ of the 4 tested spices and at $7 \mathrm{mg} / \mathrm{ml}$ of clove and cinnamon as illustrated in Table 9. The amount of AFB produced in control was quantified as $500 \mu \mathrm{g} / \mathrm{kg}$ while the AFB production is reduced to $20,30,43.8$ and $50 \mu \mathrm{g} / \mathrm{kg}$, of Clove, cinnamon, peppermint and thyme, respectively at $4 \mathrm{mg} / \mathrm{ml}$ and AFB was reduced to 22.3 and 30 at $7 \mathrm{mg} / \mathrm{ml}$ of peppermint and thyme, respectively. The use of chemical preservatives in food to abate the mycotoxin problem has disadvantages due to residual effects of these preservatives on human and animal health ( Knezevic and Serdar 2009). On the other hand, the use of natural products is considered to be safe for humans and the environment. Colonization of peanuts with mold fungi is of importance because of its potential to produce 
aflatoxins, which are potent toxic, carcinogenic, mutagenic, immunosuppressive, and teratogenic agents (Rivka 2008a, Rivka 2008b). Mould growth is commonly controlled using synthetic antimicrobials; however, natural antimicrobials had also demonstrated important antifungal properties (Lopez-Maloet al., 2000).

Table (9): Effect of spices on A.flavus growth and aflatoxins production in peanut seeds

\begin{tabular}{|c|c|c|c|}
\hline Spices & $\begin{array}{c}\text { Conc. } \\
\text { Of } \\
\text { spices } \\
\mathrm{mg} / \mathrm{ml}\end{array}$ & Fungi Growth & $\begin{array}{c}\text { HPLC } \\
\text { Afltoxins conc. } \\
\boldsymbol{\mu g} / \mathbf{k g}\end{array}$ \\
\hline $\begin{array}{l}\text { Control } \\
\text { (without spices) }\end{array}$ & - & +++++ ve & 500 \\
\hline \multirow{3}{*}{ 1.Clove } & 10 & $+\quad$ ve & ND \\
\hline & 7 & $++\quad$ ve & ND \\
\hline & 4 & $\begin{array}{ll}+++ & \text { ve }\end{array}$ & 20 \\
\hline \multirow{3}{*}{ 3.Cinnamon } & 10 & $+\quad$ ve & ND \\
\hline & 7 & $+++\quad$ ve & ND \\
\hline & 4 & $+++\quad$ ve & 40 \\
\hline \multirow{3}{*}{ 4.Thyme } & 10 & $+\quad$ ve & ND \\
\hline & 7 & $+++\quad$ ve & 33 \\
\hline & 4 & $++++\quad$ ve & 50 \\
\hline \multirow{3}{*}{ 5.Peppermint } & 10 & $+\quad$ ve & ND \\
\hline & 7 & $+++\quad$ ve & 22.3 \\
\hline & 4 & $++++\quad v e$ & 43.8 \\
\hline
\end{tabular}

ND = no detection

\section{Conclusion}

The current results revealed that row and processed peanuts were contaminated by fungi specially aflatoxigenicAspergilli. Many of these fungi are capable of producing aflatoxins. Contamination of the peanut products is a matter of health hazard for human consumption. However their safety can be insured and improved greatly by using high quality row materials. Due to health and economic consideration, natural powder spices 
may provide an alternative method to protect peanuts from fungal contamination .So, this study aims at evaluate the use of powder spices as antifungal agents to be suitable for applications on the peanuts industry. They can be used as growth inhibitors of Aspragillusflavus and its aflatoxins production. The main reason for their suitability is their natural origin, which consumers find comforting and low risk.

\section{References}

Al-Amod , O.M. Seed-borne fungi of some peanut varieties from Hadhramout and Abyan Governorates in Yemen. Journal of Agricultural Technology Vol. 11(6): 13591370.(2015).

Al-Zubaydi, S.R., Al-Hmdany, M.A. and Raesan, S.J. Antibacterial effect of some medicinal plant extracts against some pathogenic bacteria strains. Journal of Duhok University, 12(1): 244-249(2009).

Anwar, F., Ali, M., Hussain, A.I. and Shahid, M. Antioxidant andantimicrobial activities of essential oil and extracts fennel (Foeniculumvulgare Mill.) seeds from Pakistan.Flavour and Fragrance Journal, 24: 170-176. (2009).

AOAC.Association of Official Analytical Chemists.Official Methods of Analysis of AOAC International 17th ed., Nature Toxins.AOAC International, Arlington, Virginia, USA, chapter 49(2007).

Atanda, O.O; Akpan, I. and Oluwafemi, F. Thepotential of some spice essential oils in thecontrol of A. parasiticusCFR 223 and aflatoxinproduction. Food Control 2007; 18: 601-607. (2007)

Belli, N.; Marin, S.; Sanchis, V. and Ramos, A.J. Influence of water activity and temperature on growth of isolates of Aspergillus section Nigri obtained from grapes. International Journal of Food Microbiology 96(1): 19-27.( 2004).

Bokhari, F.M. Spices mycobiota andmycotoxins available in Saudi Arabia and theirabilities to inhibit growth ofsome toxigenic fungi.Mycobiology. 3: 47-53. (2007). 
Brus, W.; Horn,P. and Joe, W. Colonization of wounded Peanut seeds by soil fungi in Africa andsouth eastern Asia.Mycologia, 97: 20217.(2005).

Cordell, G.A. Changing strategies in natural products chemistry: A review. Phytotherapy Research, 4: 198-200. (1995).

Dekoe, W.J., R.A. Sanson, P.V. Egmond, J. Gilbert and M.SabinoProceedings of the international IUPAC Symposium on Mycotoxins and Phcotoxins.Guarja, Brazil, 21-25. (2000).

\section{El-Mohamady RSR, Abdel-Kader MM, El-Mougy NS, El-Gammal NG, Abd-}

AllaMA Beneficial effect of some yeast and bio-fungicides on peanut mold infection. Inter. J Eng.Innov.Tech. 3 (12):297-302. (2014)

\section{EL-Shanshoury, A.R.; EL-Sabbagh, S.M.;Emara, H.A. and Saba, H.E} Occurrence of moulds, toxicogenic capability of Aspergillusflavus and levels of aflatoxins in maize, wheat, rice and peanut from markets in central delta provinces, Egypt, Int.J. Of Current Micro. And Appl. Sciences 3(3) 852-865.(2014)

Embaby, E. M. and Abdel-galel, M. M. Detection of fungi and aflatoxins contaminated peanut samples ( Arachishypogaea L.) . Journal of Agricultural Technology .; 10(2): 423437(2014).

FAO Achievements inEgypt. http://neareast.fao.org/FCKupload/File/acheg.p df(2011).

Han, Y. Lee, K.H. Yeom, Y.K. Kim, H. Jin, V.N. The Drosha-DGCR8 complex in primary microRNA processingGenes Dev., 18 (2004), pp. 3016-3027.(2004)

Hom, B.W., RL, Green and J.W., Domer. Effect of corn and peanut cultivation on soil populations of Aspergillusflavus and A.parasiticus in southwestem Georgia, Applied Environ Microbiol 61; 2472-2475. (1995).

Horn, B.W. and Dorner, J.W. Effect of nontoxigenicAspergillusflavus and A. parasiticus on aflatoxin contamination of wounded peanut seeds inoculated with agricultural soil containing natural fungal populations. Biocontrol Science and Technolog y, 19: 249-262. (2009) 
Horn, B.W. Colonization of wounded peanut seeds by soil fungi: selectivity for species from Aspergillus section Flavi. Mycologia, 97:202-217. (2005)

Ichinoe, M.E.; H.A. Kurata, Y.B. Sugtura, Y.S. and Uemo, Chemotaxonomy of Gibberellazeawithspecial reference to production of trichothecenesand zeralenone. Applied and EnvironmentalMicrobiology 1983: 46; 1364-1369. (1983).

Kacaniova, M. Feeding soybean colonization by microscopic fungi.Trakya Univ. J. Sci., 4:165-168. (2003)

Knezevic, Z. and Serdar,M. Screening of fresh fruit and vegetables for pesticide residues on Croatian market. Food Control., 20: 419-422. (2009)

Kubatova,A. Novédruhytoxinogenníchpeniciliínalezenénapotravinách a jejíchidentifikace. (Newspecies of toxinogenicPenicilliumfound in the foods and their identification) Sb. prednášek: AktuálníproblematikamikrobiologiepotravinII.Liblice-Byšice: Dum vedeckychpracovníkuAkademieved, pp: 103-107. (2000)

Kumar, V.; Basu, M.S. and Rajendran, T.P.Mycotoxin research and mycoflora in some commercially important agricultural commodities. Crop Protection, 27: 891-905. (2008)

Leon, J.; Rojo, E. and Sanchezerrano, J. Wound signaling in plant Journal of Experimental Botany, 52: 1-9. (2001).

Lopez-Malo, A.; Alzamora, S.M. and Guerrero, S. Natural antimicrobials from plants. In: Alzamora, S. M.; Tapia, M.S. and Lopez-Malo, A. (Eds.), Minimally Processed Fruits and Vegetables. Fundamentals Aspects and Applications. Aspen Publishers, Gaithersburg, PA, pp. 237-264. (2000).

Okwu, D.E. Phytochemicals and vitamin content of indigenous spices of South Eastern Nigeria. Journal of Sustainable Agriculture Environment, 6: 30-34. (2004).

Oluma, H. O. A. and Nwankiti, A. O. Seed-storage Mycoflora of Peanut Cultivars Grown in Nigerian Savanna; Tropicultura; 21.2;; 79-85. (2003). 
Reddy, M.N and A.S. Rao.Damping off of groundnut caused by 2 Fusarium spp., F. solani and F. oxysporum Indian Journal of Mycology and Plant Pathology, 10(1): 65-66. (1980).

Rivka, B.G. AspergillusMycotoxins. Elsevier Inc, 115-151. (2008a)

Rivka, B.G. PenicilliumMycotoxins, Elsevier Inc, 153-183. (2008b)

Scott, P.M. Fumonisins. Int. J. Food Microbiol., 18:257-270. (1993)

Shotwell, O.L.; Hesseltine, C.W.; Stubblefield ,R.D. and Sorenson, W.G. Production of aflatoxin on rice. Appl.Microbiol.14: 425-428. (1966).

Singh, K.; Frisvad, J.C.; Thrane, U. and Mathu, S.B. An illustrated manual on identification of some seed borne Aspergilli; Fusaria; Penicillia and their mycotoxins. Heller up; Denmark: Danish Government; Institute of seed pathology for developing countries. P. 133. (1991).

Snedecor, G. M. and Cochran, W. C. Statistical methods.6th Ed. Iowa Univ. press. Ames. Iowa U.S.A. (1969).

Sultan, Y. and Magan, N.Mycotoxigenic fungi in peanuts from different geographic regions of Egypt.;Mycotoxin research .;26:133-140(2010).

Tian, Y.; Bi, J.; Shui, G.; Liu, Z.; Xiang, Y.; Liu, Y.; Wenk, M.; Yang, H. and

Huang, X. Tissue-autonomous function of Drosophila seipin in preventing ectopic lipid droplet formation. PLoS Genet. 7(4): e1001364. (Export to RIS)USA. (2011).

WHO (World Health Organization), Legal Status of Traditional Medicine and Complementary /Alternative Medicine: A world wide review. WHO Publishing I. ISBN, (2001).

Youssef,M.S.; El-Maghraby,O.M.O. and Ibrahim, Y.M. Mycobiota and Mycotoxins of Egyptian Peanut (Arachishypogeae L ) Seeds,Interntional Journal of botany 44:34.(2008) 


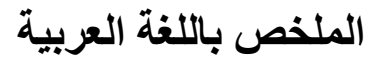

\section{التواجد الفطري في الفول السوداني المصنع والسيطره علي الفطريات المفرزه للافلاتوكسين باستخام مسحوق بعض التوابل}

\author{
مني اسحق فهد،،حسن احمد عمره2 ، فرياله عبد الحميد (بو سيف1،ولاء نبيل محمد1 \\ 1.قسم النبات_كليه البنات_جامعه عين شمس \\ 2.قسم السموم الفطريه وملوثات الغذاء -المركز القومي للبحوث
}

نظر اللمحتوي البروتيني العالية و المحتوى الدهن و اصبح الفول السوداني موضع تقدير إلى حد كبير من قبل المستهلكين ولكن أيضا عرضة للتلوث الفطرياتيشار إلى أن هناك خطر محتمل للتلوث بالفطريات المفرزه

للافلاتوكسين في الفول السوداني الصصنع في مصر و التي تتطلب مقاومة هذه الفطريات يهدف العمل الحالي الي الي التيات در اسه التو اجد الفطري في انواع من الفول السوداني المنتجه الي جانب دراسه الخصائص المضاده للفطريات لعشره

من التو ابل (القرنفل، الفلفل الأسود، القرفة، النعناع، الزعتر، الهيل، الكمون، الزنجبيل، البصل و الحلبة

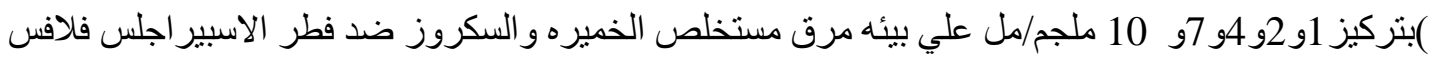

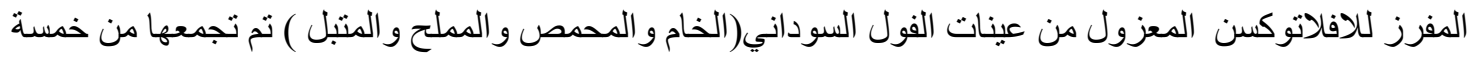
محافظات (القاهرة و السويس و المنوفيه من شمال الدلتا والفيوم والاقصر من جنوب الدلتا) خلال سنة واحدة من (شتاء عام 2013 لخريف 2014).اظهرت النتائج عزل أربعة أجناس الفطرية جنس الاسبرجيلس بنسبه

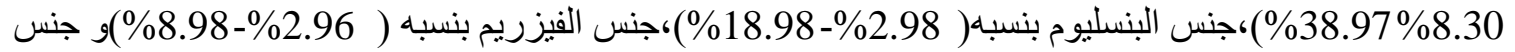
الريزوبس(989\%- 11.95\%)وكان جنس الاسبير اجلس فصيله الفلافي اكثر شيوعاوقد اظهر التحليل الاحصائي

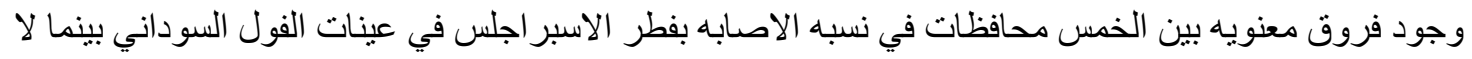
توجد فروق في الاصابه بباقي الاجناس المعزوله .و اظهرت النتائج ايضا ان فطري الاسبير اجلس فلافس الاسير و الاسبير اجلس بارازيتيكس المعزولين من عينات الفول السوداني مفرزه الافلاتوكسن .و عنند دراسه خو اص التها التوابل

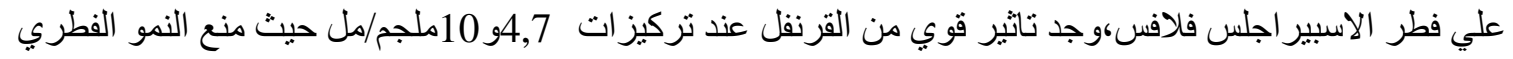
وكنلك انتاج الافلاتوكسين بنسبه 100\% علي الوسط الغذائي السائل و عند التطبيق علي حبوب الفول السوداني ،بينما مع باقي التو ابل وجد نمو فطري عند تركيز 10 ملجم/مل ولكن منعت انتاج الافلاتوكسن ولكن عند تركيز ملجم/مل كان هناك نمو فطري وكذلك انتاج للافلاتوكسين .عند التطبيق علي حبوب الفول السوداني باستخدام (القرنفل و الزعتر و النعناع و القرفه) وجد عند جميع التركيزات نمو فطري بدرجات مختلفه و اقلهم عند القرنفل بتركيز

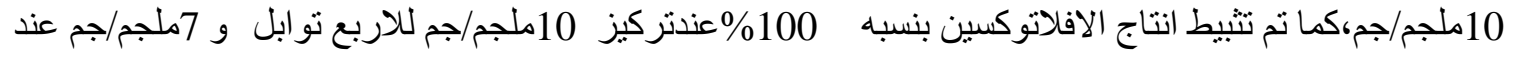


القرنفل و القرفه فقط بينما النعناع و الزعتر كانت نسبه انتاج الافلاتوكسين تتر اوح من 22.3-33\% و عند تركيز

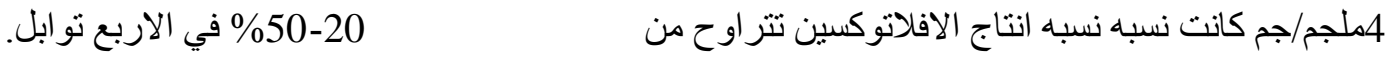

